\title{
皮䖉充血剂使用時の皮虑および皮下 結合織線組系についての実験的研究
}

\author{
岡山大学炏学部整形外科学教室（主任・児玉俊大教授）
}

名越孜

(昭和34年 6 月29日受㼛)

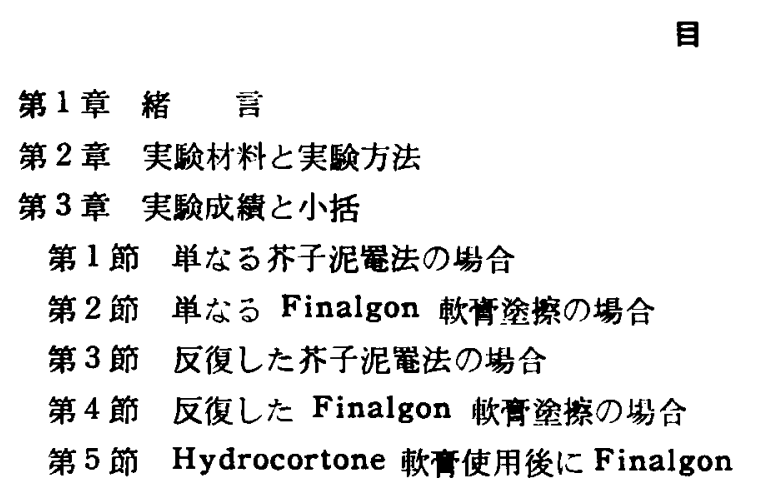

\section{事1革 緒}

スポーツ外俄やスポーツ障害,およじリウマチ性疾 患に用いられる，合成皮居充血剂，Finlagon 軟高 を, 岡山大学以学激附属病院整形外科に於てリウマチ 様関節炎患者に使用して比較的良い結果を得たが，綝 返して闹一部位に使用すると，患者の皮消の被刺戟性 が低下して，効果が減退する事があ，馴れの現象と 呼んだ.

Finalgon 軟抒は $\beta$-butoxyethyl ester of nicotinic acid $2.5 \%$, nonylic acid Vanillylamide 0.4\%，を主成分とし，Achinger'（1952）によれ ば，前者は毛細血管の自律神経存刺戟して強力な血管 抬張作用を起させ，後者は胡椒の有㱛成分Capsaicin に化学的に近似して居り, 皮㐿の感觉神程終末に作用 して，二次的に毛細血管の拡張を起させると云う。 我が国では古くから苏子罢法が神経捅，リウマチ, 肺炎等に奖用されているが，芥子の有刘主成分はシニ クリンと云う配瞊体と、ミロジンと云う酵素とで、シ ニクリンは水と温かさとを得るとミロヂンによつて分 解されて，揮発性芥子油在じ，揮発性と油脂溶解性: によつて皮后内に入つて刺戟作用を現わすと考えられ ている2!，私は芥子篗法で二十日鼠の皮下結合組織か 刺戟される事から 皮庙と皮下結合組織に及ぼす作朋在，奵片喍本の
次

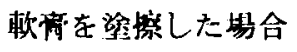

第 6 節 $5 \%$ Salicyl 酸 Natrium 棓水性 Vaselin 軟语等の昜合

第 7 節 単なるHydrocortone 僛青塗㨲の湯合 第 4 章 拷按と総括

第 5 章 結 浯 主要参考交献

Haematoxylin-Eosin 重染色標本と, 薄膜標本の Möllendorff 氏鉄へマチンラック染色 ${ }^{3}$ 標本について 比校して見た。またりウマチや皮䖉矣患の際に使う Hydrocortone 粐等として使用した時の皮后への洛 達範用と作用の強ざを约るために Finalgon 軟帝と 作朋して見た。さらに Salicyl 酸製威は抗炎症剤や 鈛湤剤として一般に内服されているが，軟高として局 所に用いた垬合の皮屑及び皮下の結合組䄉におよぼす 俳用を検して見た.なお Möllendorff 氏鉄へマチン ラック染色は線組系の変化を知るために用いた。

線組系とは Möllendoff (1926) 3 ) が粗性結合組䜌 の線維細胞の変態能力について知見を発表してから， 网" とその咕力者達が此の方面の研究を進めて, 細網 队皮系統 (網内系) に対して線組細胞系統（線組系） 亡名付けて対立させたものである。

これは普通の結合組蟣の線維細胞と粘膜の細絧細胞 上，それ等が変化しまたはそれ等から生ずる細胞を一 括して名利けたもので、楾䧽細胞は刺戟されると、ア メーバ樣になつて活動し，突起在䊒めて肥大し，線縕 球なる過梨を䅅て組織球になり，刺戟が急であると綵 維細胞から単核球になり, 䩖核球も組峨球になり得る

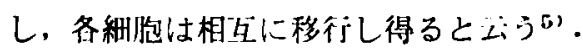

\section{第 2 章 実験材料と実験方法}

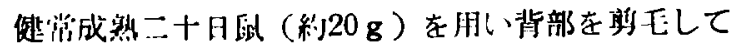




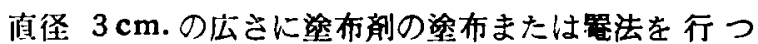
て, 一定の時間的経過に従つて, 皮下組織の小片を採 り，薄脱漂本を作り，10\%ホルマリン水で固定，Möllendorff 氏鉄へマチンラック法で染色，他方同部の 皮成小片を採り $10 \%$ ホルマリン水で固定して，パラフ インで包埋して5〜7 $\mu$ に切り Haematoxylin-Eosin 重染色をした。

\section{实非方法}

1）日本薬局方の芥子末を 2.5 倍活力 $40^{\circ} \mathrm{C}$ の湯によ いて泥状となし，10分間密閉放置してから硝子棒で ランネルにのばして㲜物の背部に貼付し，ホール秪を あてて、紏㓱で固定し10分の後除去した。炐れの実 跧の场合には. 5 分で除去し 4 日川每に5 回繰返した 後標本を採门始力，5回目の䁬法をする直前のものを 対照とした。

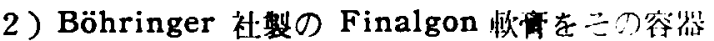
より䄪 $2 \mathrm{~mm}$. しぼり出して動物の背部に直径 $3 \mathrm{~cm}$. の広さに準擦し，30分問油紙で覆つた後標本を採り始

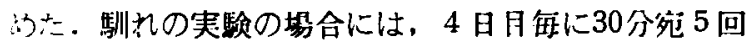
綝返した後標本を採り始め，5回月の涂擦の直前に採 つたものを対照とした。

3) $5 \%$ Salicyl 酸 Natrium 視水性 Vaselin 㳄 号 (以後 Salicyl 酸 Natrium 顿高と略称する) Finalgon 㳄高と同程度に動物の背部に叙擦して30分 後から磦本を採り始めた。

4) 日本メルク万有社製,局所用 Hydrocortone 吹 型 (Hydrocortone acetate $1 \%$ 含有) を容器加 51.5

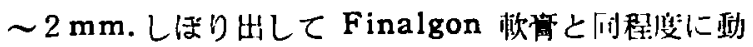
物の背部に梁擦して30分後にその上に Finalgon 敕惊

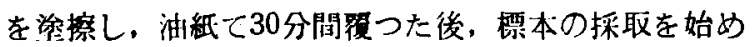
太。

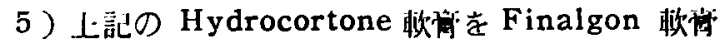

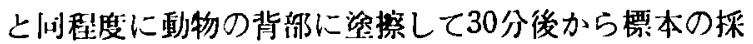
取始めた。

各実験に於て，闰一日的のために動物を各々 3 䫓行 用い，薄膜標本は各々より 3 枚宛の標本を造つて, 各 タについて細胞数 $600 を$ 数えて, 稩胞の種数の100分率 を求め，平均の值を出した，闪時に频微鏡所見を記睩 した。標本採取は対照として，处置犃のもの（䟝れの 場合には最終回の処固の直前のもの）を採り，処直が 䅂つてから 30 分， $1 ， 2 ， 3 ， 4 ， 5 ， 6 ， 8 ， 12$. 24 時間 2，3，5 日， 1，2，3，4週のものを採つ たが、記截は主要時間のみに限つた。

線組系の像を简単に表わすために関の) 等は次の略語 を用いているのでこれを使用した。
F 型（線維細胞型）：Fbc（線組細胞）が全細胞の 70〜80\%またはそれ以上を占めるもの.

F H型（線組球型）：Fbhsc（線組球）とHsc（組 繀球）が最多で，全細胞の50〜60\%を占めるもの.

H型（組織球型）：どの細胞種よりも Hsc（組裁 球）が多くて，全細胞の30〜40\%，またはそ机以上を 占めるもの.

MH型 (単組球型)：Mnc (単核球) と小型のHsc （組織球）が多く，両者を合せると，全細胞の50〜60。 \%に達するもの.

M型（単核球型）：Mnc (単核球) が最多のもの.

L 型（白血球型）：Lkc'（孔核白血球様 細胞）之 Lkc (白血球) が最多のもの.

Prod 型（增殖型）：諸種の細胞，特に Fbc（線䧽 細胞）とFbhsc（線組球）が甚だ多くなり，それが 概して小形のもの.

Atr 型（淩縮型）：細胞が一般に瘦せ，胞形質の染 色性が減じ，特に線維稩胞の胞体の輪遊が甚だ不明瞪 なもの.

$1 つ の$ 動物で或る所はF 型, 或る所はF H 型でるる 場合はF，FH型と祀载する．同様に FH， H 型， H, MH 型，F，Atr 型等とする．大体はF.型であるがや やF H型の濒向がある場合には F (F H ) 型と記载す る.

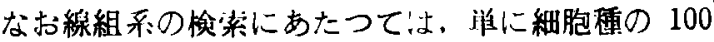
分染にとらわれる扑なく、紐胞の形態的推移を考览し て㙕智の判定の参考とした。

\section{第3章実 験 成 緼}

\section{第 1 節 单なる芥子泥法法の坦合}

\section{1 ）線組系の所見}

篦法を忖めて30分後には，Fbc（線維細胞）は突起 を縮め Fbhsc（線組球）への移行をし始めている。 1 時間後には F ( F H ) 型となり Fbc にも空胞を持 つものが現われ，Fbhsc，Hsc（組峨球）は小型では あるが增加し，処どころには1 個の胞体内に 2 個の核 を有するものもある. 大小の Mnc (単核球) が散見 され亜鉿型の核を持つものも見られる，2時間後には これ等の种胞は胞体を增人し空跑も大きくなるが未だ F (F H ) 型である。 3 時間で F，F H 型となり，4 時間でも F、H型であるが最も赋活された像を示し， 殆どの紏胞に空胞が見られ，Fbhsc，Hsc の数を增し 核を 2 倜有するものも見られる（写真No. 2)．6時

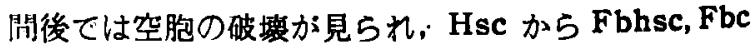
へ移行を思わせる.12時間後はF，F H型となり空胞は 
更に破れ，胞体の突起を伸ばして網目様に連りつつあ ろ. 24時間後はF (F H) 型, 48時間後はF型て殆ど 正常に近く，各稩胞は僅かに空胞を残すのみである. 1 䓢間で全く正常像に復する（表Ｉ）。

第 I表 単なる芥子泥䍒法の昜合の二十日鼠 の皮下結合檄線組系の\%

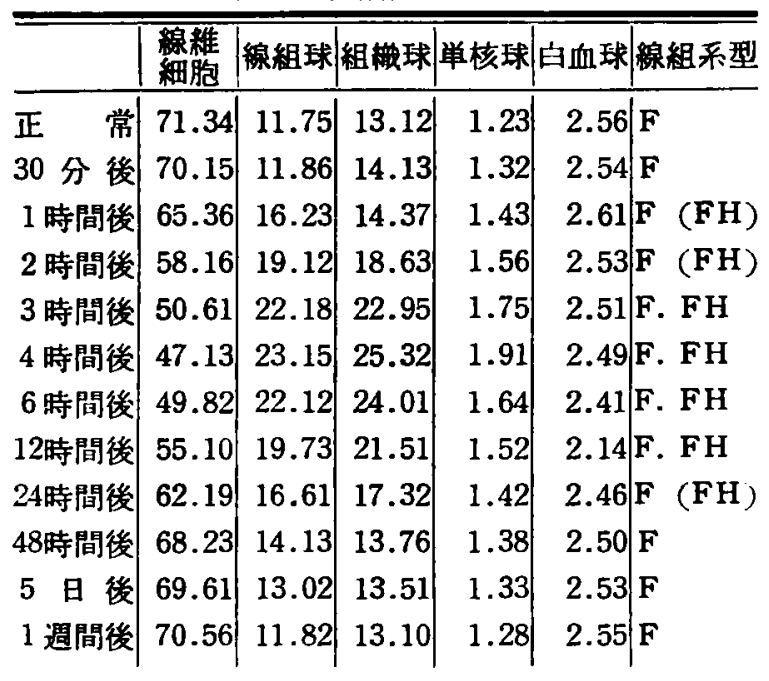

\section{2) Haematoxylin-Eosin 重染色標本所見}

30分後には表皮角貿層の強い融解䟝離を認め, 真皮 層の毛紐向管には軽度ないし中等度の充血あり血管篦 に白血球が集中し，さらに血管周明に向つて遊出し始 认，血管賆内にも白血球を認める. 浮腫は真皮全層, 箭層の近くに迄あり，中等度である.滕原線維が無構 造になりかかつている所が稀にある。1時間後では浮 㬴注增々強く，白血球の遊出も更に進み真皮下層に向 つているが充血は余り增強していない.膠原線維の無 構造化が更に明暸になつて来ている，2時間後では周 原線維の変化は進んていないか，他の所見は增強して いる．3時間後も全般的に変化は軽度に增しただけで ある. 4 時間後では表皮の角質增加を訆め，白血球の 缶润は真皮の深層から筋層にかけて強く、大部分は多 核向血球で単核白血球も少数ある. 膠原楾稚の無構造 化はあまり進んでいない.6 時間後には真皮層の底,筋 層，筋層の下にも多核白血球，単核白血球の浸潤は一 同強く, 此の部では器質化が始つているのではないか と考えられ，大単核球，組織球性の細胞も見られる， 具皮下層の充血は依然として強い，12時間後では角㧤 增加は落着き，充血は大分減じ，浮腫も真皮層には㱠 と訆めないが，白血球の浸潤はかなりある. 真皮浅層 から特に深層更に筋層附近にかけて組織球性の細胞が 多く,また乳頭下の無構造になつた膠原線稚の附近に 線稚芽紐胞を認める。24時間後には更に此の偭向が進
んで居り４8時問では充血は真成層にかなりあるが浮 腫は己れ程強くない，細胞浸潤も殆ど認めない，表皮 角啠風の㔀離が強い. 所見は徐々に娍じ1週間で台ど 正常の像に復㛿する。

3) 小 括

芥子泥の10分問の䍘法では 4 時問頃に炎症性の变化 が最も強く,単なる皮庙の充血でなく,真皮から筋層の 近くに及ぶ浮腫, 細胞浸洞, 膠原線維の無䅹造化を認 めた. 皮下粗性結合織の線組系も, $3 \sim 4$ 時間頃に最

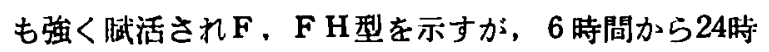
間にかけて比校的速やかに正常化し，48時間では殆ど 正常に近い像となり，1週間で全く正常に復帰した像 を認める。

\section{第 2 節 単なる Finalgon 軟需造拯の坦合}

1) 線組系の所見

Finalgon 軟音の被覆を外して30分後に既にFbcは 笑起を短樎し、賦活されているのがわかる１時間後 には突起は更に短繀し, Fbhsc とHsc の增加して 来た所もあり， F ( F H ) 型となり，2 時間後に小型 の Fbhsc, Hsc が現れ始め, 空胞をもつたものもあ ろ. 3 時間後ではF. F H 型となり Fbhsc, Hsc も 肥大し空胞も更に大きくなり核を 2 佔持つものもあ る. 4 時間後ではF，F H型であるが最も強く㽣活さ れた状態にあり，Hsc，Fbhscは增して居り，圶 胞も大である (写真No.3).6時間後では, 空胞は 大きいか，Fbc は胞体を伸はして笑起を出して連り 始める.8 時間後にはF (F H) 型となり此の傾向は 更に強く,12時間後には大きな空胞が破れ始めてい る. 24時間では未だ空胞が残つていて細胞の畞活の跡 を止めているが，48時間後にはF 型となり，数日の間 に正常化か更に進んで 1 週間では殆ど跡を残さず正常 に州る（表II）。

2 ) Haematoxylin-Eosin 重染色標本所見 30 分後には表皮角質風の融解䟝離が軽度にあり, 乳 顽下から真皮下層にかけて毛細血管の充血が㸱度にあ る。1 時間後には此の傾向が更に進み，2時間後には 真皮全層に軽い浮腫を認める。3時間後には血管周囲 に白血球か極く軽く浸潤している所もある。.又血管周 辺の浮腫が他の部に比して軽泊に優つている.4 時問 後には表皮角質層の融解剥離は軽废〜中等废となり，

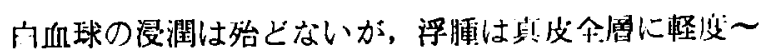

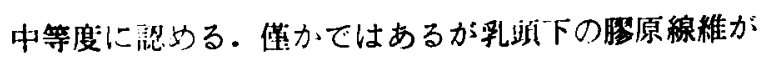

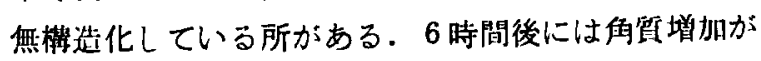

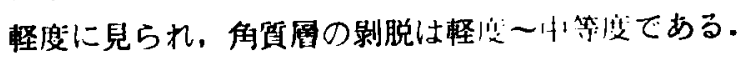


第几表 単なるFinalgon 軟佮塗擦の場合の 二十日鼠の皮下結合艠線組系の\%

\begin{tabular}{|c|c|c|c|c|c|c|}
\hline & $\begin{array}{l}\text { 線稚 } \\
\text { 稩胞 }\end{array}$ & 線維 & 組織球 & 単核球 & 了血球 & 楾組系型 \\
\hline 常 & 71.34 & .75 & 13.12 & 1.23 & 2.56 & $F$ \\
\hline 0 分 後 & 7 & 91 & 71 & .29 & .48 & $F$ \\
\hline 1 時間後 & 68.28 & 23 & 8 & .32 & 2.41 & $\mathrm{~F}(\mathrm{FH}$ \\
\hline 2 時問後 & 62.92 & 16.09 & 17.17 & .46 & 2.36 & $\mathbf{F}(\mathbf{F H})$ \\
\hline 3 時間後 & 53.41 & 21.92 & 20.71 & .64 & 2.32 & F. $\mathrm{FH}$ \\
\hline 4 時間後 & 50.35 & 23.47 & 22.18 & 1.73 & 2.27 & F. $\mathrm{FH}$ \\
\hline 6 時間後 & 52.67 & 21.73 & 21.56 & 1.75 & 2.29 & F. FH \\
\hline 8 時間後 & 60.29 & 17.16 & 18.71 & 1.73 & 2.21 & $F(\mathbf{F H})$ \\
\hline 2時間後 & 63.32 & 15.03 & 17.61 & 1.72 & 2.32 & $\mathbf{F}(\mathbf{F H})$ \\
\hline 24 時間後 & 65.62 & 14.01 & 15.28 & 1.74 & 2.35 & $\mathbf{F}(\mathbf{F H})$ \\
\hline 48時間後 & 68.31 & 13.16 & 14.57 & 1.73 & 2.23 & F \\
\hline 5 日 & 70.62 & 12.05 & 13.82 & 1.74 & 2.37 & $\mathrm{~F}$ \\
\hline 1 週問後 & 72.02 & 11.01 & 12.69 & 1.75 & 2.43 & $\mathbf{F}$ \\
\hline
\end{tabular}

充血は中等度であるが、白血球の浸潤はない，浮䐉は 真皮深層に軽度にあるのみである。乳頭下に線維芽紐 胞を認める所もあり, 真皮深層と筋層の附近に組織球 性の細胞を認める.8 時問以後は充血，浮腫其に徐々に 诚弱し，細胞浸潤も見られず，24時間後には極く柽度 に真皮全層に浮腫を認め, 真皮の細胞数がやや多数に 見兰るのみである.48時間後から数日て殆ど正常像に 復井する。

小括

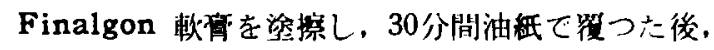
皮成及ひ皮下結 合組䄉は芥子泥䉓法後に似た变化の 反応を示すが，浮腫，細胞浸洞，器留的変化を思力女方 膠原線維の無粠造化, 表皮の角質增加等の变化は, 芥 子泥䍜法の場仓程強くなく, $3 \sim 4$ 時間で栖期に涬し， 幾分早く正常に復㷌するもの上見られる。皮下粗性絬 合組䄉の線系も Haematoxylin-Eosin 厚染色然本 の変化と略並行して居り， $3 \sim 4$ 時間後に最も畘活さ れた状態になり，F，F H型を示すか，8時問日䐜か ら徐々に正常像に向い，48时間後から数日内に正党に 復する。賦活の剭度は芥子泥罯法の埸合より弱い。

\section{第3 篮 反是した芥子泥是法の场合}

Finalgon 軟高を繰返し人体に連用した䋆合に，皮 用か：Finalgon 軟高の刺戟に対して反応しなくなる 事があるので，芥子罪法によつても頑似の操作をして みるために，反復して䍒法を行つた。

\section{1 ) 線組系の所見}

4 日間隔に 4 回, 5 分間宛芥了篦法をして第 5 回日 の罨法を行う直前のものでは, Fbc の多い, F, Atr 型
を示し，亡゙の細胞も胞体が少く，染色性に乏しく輪廊 も不明膫て、消退しかかつた空胞を持つていたが（写 真No. 4 ), 第 5 回目の芥子電法により弱いながらも賦 活されるのを認める.1時間後には F, Atr 型である が空胞は少し大きくなつて居り，4時間後で，F（ F H) 型で (写真No. 6 ), 全般的に稩胞の輪酣は稍々 朋膫化し空胞も增し少し大きくまた明膫になり，孔核 向血球様科胞が增して来て、線維細胞様の胞体がある ものもある８時問後では $\mathrm{F}$ 型となり空胞は破れたも のが多く，再び細胞の輸厭は不明潦になりつつあり， 線維芽細胞が散見されるが荌縮の感が強い，24時間後 には正常像に向う㥧向かかなり見られる．以後各練胞 は徐々に空胞を减じ，胞体を增して正常のF型へと向 い１ 1 週間後には未だ萎縮した感の像を呈している が, $2 \sim 3$ 週間で正常像に復する.

2 ) Haematoxylin-Eosin 重染色骠本所見 代子铪法を 4 日間隔に 4 回行つて第 5 回目の䍒法の 直前では:表皮は萎樎の傾向が認められ，角嘼層の影脱 は篎万多く，基皮にも菱縮の傾向があるが毛細血管に は極く軽い充血があり，哚層には毛細血管の発達を認 める. 第 5 回日の器法を止めて 1 時間後には角質層の 䟖脱が少し增し，乳頭直下の毛細血管は極く柽度に， 泪皮深周の毛紐血管は中等度に充血し白血球が集り， 血管壁队にあるものや遊出してい、もものがある。浮䧃 は真皮浅層は軽く，㳭層から筋層にか十て中等㡲にあ る. 4 峙閏後では充血は中等度よなり，表皮直下や血 管周囲の白血球浸潤か更に增し，筋層の附近迄，深部に なる剭強くなつている，浮腫は血管周辺に增す，真皮 の哚風には毛細向管の新生を認める．8時間以後は角 貿層の别脱は更に強くなるが，充血，浮腫は城じ，真

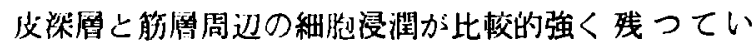
て，炎聇所兒は深部に強い，24時間後では角質增加の 倠淌老生じ，充血は軽度〜中等度で，浮腫は更に減 じ, 乳頭直下に線維細胞や線維芽細胞を認める. 以後 充血，綀胞浸润，線維細胞等も徐々に落着き正常化す るが，2 週間後には乳䫓直下に炎症性細胞が散見され 两急性炎症の跡を思わせる．3 週問て殆ど正常像に州 当.

\section{3) 小 括}

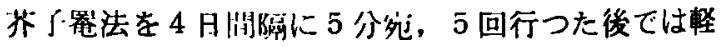
い巠急性炎症㥞の像を認め，単なる芥子䍒法の場合の 様に放感に強くは反応を示さないか，弱い炎症性反応 を示して，4恃間目頃に最も強く以後は器質化様の過 玨をとり乍ら 3〜4 週間で正常像に㷌る.皮下粗性結合 䄉の線組系は，反復した芥子買法によつて F，Atr 型 
第亚表 反復した芥子泥喽法の場合の二十日的 の皮下結合織線組系の\%

\begin{tabular}{|c|c|c|c|c|c|c|}
\hline & $\begin{array}{l}\text { 線稚 } \\
\text { 細胞 }\end{array}$ & 線租球 & 組 & 単核球 & 白血球 & 楾組乔型 \\
\hline 正 常 & 71.34 & 11.75 & 13.12 & 1.23 & 2.56 & F \\
\hline コントロ & 84.03 & 6.02 & 6.71 & 0.90 & 1.34 & F. Atr \\
\hline 1 時間後 & 80.54 & 6.52 & 8.65 & 1.73 & 1.55 & F. Atr \\
\hline 4 時問啳 & 65.47 & 14.56 & 13.83 & 2.07 & 4.07 & $F(F H)$ \\
\hline 8 時間後 & 66.85 & 14.21 & 13.59 & 1.98 & 3.37 & $F$ \\
\hline 24時間後 & 67.03 & 13.77 & 13.03 & 2.21 & 3.36 & $\mathrm{~F}$ \\
\hline 3 日 後 & 67.58 & 13.31 & 13.11 & 2.19 & 3.81 & $\mathrm{~F}$ \\
\hline 1 異間後 & 69.26 & 12.79 & 13.51 & 2.17 & 2.27 & F \\
\hline 2 週間後 & 71.27 & 12.55 & 12.68 & 1.93 & 1.57 & F \\
\hline 3 週間後 & 72.26 & 11.67 & 12.35 & 1.89 & 1.93 & F \\
\hline
\end{tabular}

となり，第 5 回日の芥子䍗法に対して弱く反応して。 4 時間月頃にF（F H) 型となり，やはり秝縮した些 のF型を程て 2〜3 週間で正常像に復寸る.

\section{第4 節 反覆した Finalgon 軟第洼摖の場合}

\section{1) 線組系の所見}

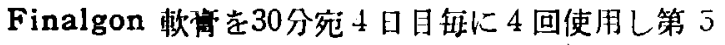

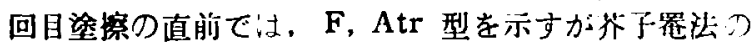
问し時期のものよりは娄綰が軽度てある。Fc か多 く，楾維芽細胞もかなり見られる.殆とつ維胞文，胞 体が不明暸で，少なく，大小の空胞を持つている（再 真No. 5 .)

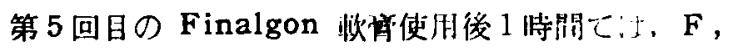
Atr 型ではあるが何れの細胞も賦活されて笑起を短秎 し始め, 4 時問後に F(FH：型となり空胞は大小多数

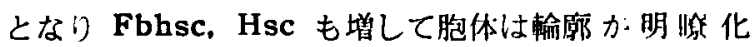

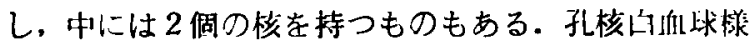
細胞も比较的多く見られる. 反復した芥子吐法の場合 よりも賦活は少し強く現われる(写真No.7).8時 間後にはF型で空胞は破れ始め，胞体は突起で速り，

線維芽細胞が少し增して来て正常化入復齊の倾向が兄 えるが末だ各細胞はかなり萎縮しているる.24時間後は $\mathbf{F}$ 型で正常化の傾向が更に強くなり，空胞はあるが各 細胞共に胞体が大となつている. 2 大 週間で正常に 㷌るが莽子唯法よりもFinalgon 忺焦は作用が稳やか であるので多少正常復帰が早いようである（䒾IV).

2 ) Haematoxylin-Eosin 重染色標本所見

Finalgon 軟 4 日問隔で30分宛 4 回使用し，第 5 回目の塗擦の直肺では，表皮はやはり萎樎の㑯向が 見られ，角質層㔀晟はかなりある。

真皮深層には毛細血管が極く軽度に発達して来て居 り，充血，浮腫は真皮全層に軽度で，細胞浸洞，出血 を認めない，第 5 回日の塗擦の 1 時問後には中等倎の
第1V表 反復した Finalgon 㳄们染擦の場合 の二十日鼠の皮下結合織線組系の\%

\begin{tabular}{|c|c|c|c|c|c|c|}
\hline & $\begin{array}{l}\text { 線維 } \\
\text { 紐胞 }\end{array}$ & 線組脙| & 組 & 単核 & 白血球 & 線組系型 \\
\hline 正 常 & 71.34 & 11.75 & 13.12 & 1.23 & 2.56 & $\mathbf{F}$ \\
\hline & 81.98 & 7.39 & 7.06 & 1.33 & 2.17 & F. Atr \\
\hline 1 間後 & 79.24 & 7.38 & 7.91 & 3.45 & 2.02 & F. Atr \\
\hline 4 時間後 & 66.15 & 15.01 & 14.53 & 2.05 & 1.36 & $\mathrm{~F}(\mathrm{FH})$ \\
\hline 8 特間後 & 69.13 & 13.52 & 14.11 & 2.03 & 1.21 & F \\
\hline 24封間後 & 68.55 & 13.36 & 13.56 & 2.04 & 2.49 & F \\
\hline 3 日後 & 69.98 & 12.92 & $13.2 \overline{\mathrm{z}}$ & 2.06 & 1.79 & $F$ \\
\hline 1 週間後 & 70.89 & 12.34 & 13.16 & 1.09 & 2.52 & $\mathrm{~F}$ \\
\hline 2 週間後 & 71.03 & 11.99 & 13.51 & 2.02 & 1.45 & $\mathrm{~F}$ \\
\hline 3 週間後 & 71.68 & 11.83 & 13.46 & 2.01 & 1.02 & F \\
\hline
\end{tabular}

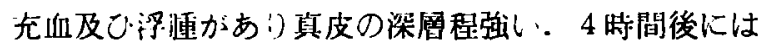
角啠增加を認めるが角留䟝離は怪度である.浮腫, 充血 は真皮深風に軽度または中等度にあり，乳頭直下の膠 原楾維の無棈造化している所が茎かに見られる。过皮 梁層の毛紐血管の発達は充血によつて一層朋暸にな る.管原の周辺には，組織琲性細胞を諗める８時間

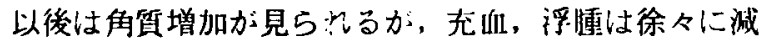

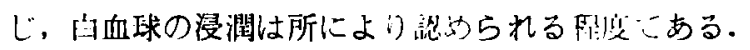
真皮には線維租胞，線維芽勫胞が偘かに現力れてい る。炎症像は徐ヶに修復されて 1 週間後には倬かに炎

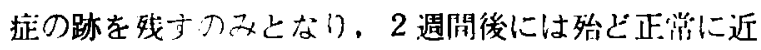
く 3 週間後には全く異常在認引心い.

3) 小括

Finalgon 軟旁を 4 日間隔で30分宛 5 回使用した場 合は，芥子罨法を 4 日間隔で 5 分宛 5 回繰返して行つ た場合よりも軽传ではあるが皮庙は萎䑿性となる。角 質層の剔脱はかなりあり，真皮深凰には电細血管の軽

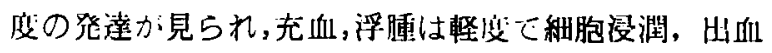

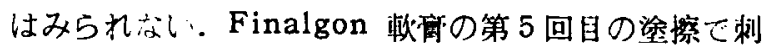
戟されるが反応は単なる Finalgon 㳄染塗擦の场命 よりも弱，桴膄，充血は真皮深㬝に埾度〜中等度に

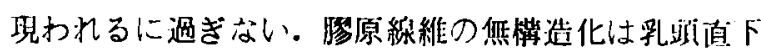
に僅かにある梨度である。

反応は 4 時間後頃が極期て $2 \sim 3$ 週間で正深像に㳯

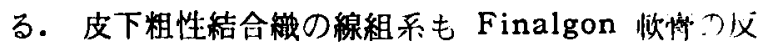

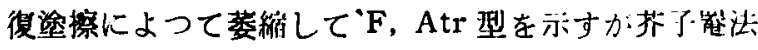
を反復して行つた場合よりも軽度で，Finalgon 惞悯

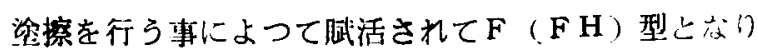

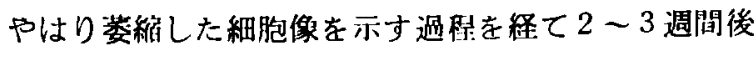

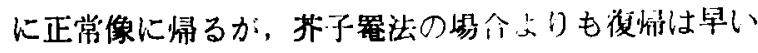
ようである. 


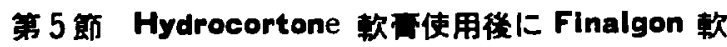 再を璱探した场合}

1) 線組系の所見

Hydrocortone 㳄高在塗擦して30分後に Finalgon 杴骨を鉒擦し30分間油䄳で覆つた後 1 時間目にはF型 て，楾維芽細胞が少し多く見らするがよ゙の細胞種にも 空胞のあるものは殆ど見られない４４時問後にも F 型てあ门，空胞が增し，細胞は笑起を縮めて居り， Fbhsc, Hsc の数が幾分增しているので線組系が倵活

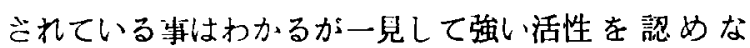
し. 8 時間後には闹じく $F$ 型で，既に正常化に向つて 居り，胞体の榆硧は不明燎となり突起を伸ばして連り つつある.24時間後には殆よ゙正常に近くなり，3日〜 1 週間で全く正営像に州る（表V）.

第 $\nabla$ 表 Hydrocortone軟搒を使用し太後に Finalgon 吹耍签徖した場合の二 十日鼠の皮下結合織線組系の\%

\begin{tabular}{|c|c|c|c|c|c|c|}
\hline & $\begin{array}{l}\text { 線維 } \\
\text { 細胞 }\end{array}$ & 線 & 組織球 & 単核球 & |白血球 & 線組系型 \\
\hline 正 & 71.34 & 11.75 & 13.12 & 1.23 & 2.56 & $\mathrm{~F}$ \\
\hline 1 時問後 & 70.50 & 12.77 & 13.13 & 1.24 & 0.36 & $\mathrm{~F}$ \\
\hline 4 時間後 & 67.32 & 14.23 & 14.92 & 2.08 & 1.45 & F \\
\hline 8 時間後 & 67.66 & 14.01 & 14.52 & 2.02 & 1.79 & F \\
\hline 24時問後 & 68.51 & 13.03 & 13.91 & 2.87 & 1.68 & F \\
\hline 3 日後 & 69.27 & 12.81 & 13.42 & 2.58 & 1.92 & $\mathrm{~F}$ \\
\hline 1 週間後 & 71.03 & 11.87 & 13.26 & 1.82 & 2.01 & $\mathrm{~F}$ \\
\hline
\end{tabular}

2) Haematoxylin-Eosin 重染色磦本の所見

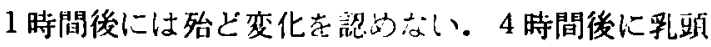
下に軽い无向，乳䫓下と真皮全風に亘つて柽度〜中等 度の浮腫がある.8時閻後には仵留首の䟝脱が少し強 まつている.充侮，浮腫は軽度に真皮全層に見られ る.24時間後には卶ど正常像上なる。

3) 小括

Hydrocortone軟育を塗㨲してから30分後にFinalgon顿等を使用した場合に，皮清の反応も，線組系の 倵活も強くは現われない，線組系は 4 時間目頃に陚活 された像を示すが $\mathrm{F}$ 型で，24時間後には殆ど正学化し 3 日〜 1 週間で全く正常となり，HaematoxylinEosin重染色標术ては24時間後には殆ど正常像となる。

\section{第 6 節 5\%Sallcyl 酸 Natrlum 親水性 Vaselin軟 雨金操の合（以下 Salicyl 酰 Natrium 軟面と略称する)}

1 ) 線組系の所見

Salicyl 酸 Natrium 吹唋擦して30分経てから

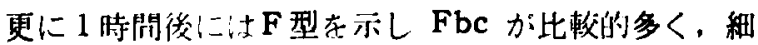

胞は全般的に染色惯に乏しい，4時間後にはF(F H) 型となり，空胞も增し，Fbhsc，Hsc も增すが，Fi-

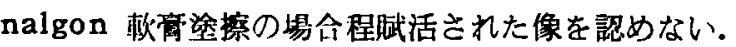
孔核白血球様細胞にも胞体が增し空胞を持つものがあ る. 6 時間後にはF ( F H ) 型であるが空胞が破れ胞 体は正常化に移行しつつある像が見え，8時間後では 空胞はかなりあるが破れていて正常化への傾向は更に 進んでいるＨsc の中には核を 2 偑持つものが見ら れる.24時問後にはは略正常像になる(表VI).

第VI表 $5 \%$ Salicyl酸 Natrium倸水性 Vaselin 䎶青染擦の場合の二十日鼠の皮下結合樴 線組系の\%

\begin{tabular}{|c|c|c|c|c|c|c|}
\hline & $\begin{array}{l}\text { 楾維 } \\
\text { 細胞 }\end{array}$ & 線組球 & 組編 & 単核 & 白血球 & 線組系型 \\
\hline 常 & 71.34 & 11.75 & 13.12 & 1.23 & 2.56 & $F$ \\
\hline 1 時問後 & 72.57 & 11.82 & 14.52 & 1.28 & 2.41 & F \\
\hline 4 時間後 & 66.32 & 15.01 & 14.85 & 1.39 & 2.43 & $\mathbf{F}(\mathrm{FH})$ \\
\hline 6 時間後 & 66.75 & 14.86 & 14.64 & 1.37 & 2.38 & $F(F H)$ \\
\hline 8 侍間後 & 69.51 & 12.23 & 14.06 & 1.36 & 2.84 & F \\
\hline 24 時間後 & 72.03 & 11.91 & 13.22 & 1.35 & 1.49 & F \\
\hline
\end{tabular}

2) Haematoxylin-Eosin 重染色標本所見

Salicyl 酸 Natrium 軟碚を塗擦して30分程てから 更に 1 時問後には表皮角偭風の䟝脱, 真皮の充血, 浮 槚は何れも極く柽废である４時間後には，これ等の 所見は軽度〜中等废乞なり，8時間後には真皮の処々 に浮軞を認める外には殆よ゙变化がなく，24時間後に正 淌像に復愞する。

3) 小 括

$5 \%$ Salicyl 酸 Natrium 親水性 Vaselin 軟等塗 擦により皮有の立血，浮腫，表皮角额層の䟝脱は軽度 に起り，4時間後の所見が最も強く，24時間後に正常像 に惼引。線組系の所見では 1 時間後には線維細胞の陚 活が弱く染色性にこしく，強い反応を亦さない.胞体 のある孔核白血球㴍細胞も現わ礼る４時間後には最 も変化か強くF( F H ) 型となり，24時間後に正常像

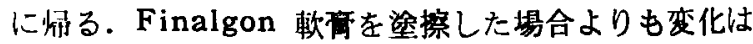
少ない。

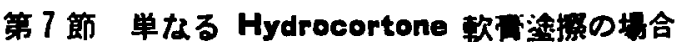

\section{1) 線組系の所見}

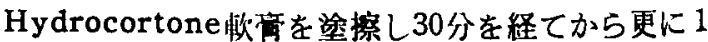
時間後では概㕲F型であるが Fbc の染色性がややそ しい所もある. 3 時間後には F 型で稍々活性化し比較 的大きい空胞を标するものも現われて来るが Fbhsc, Hsc はあまり增していない，4時間後頃から空胞が 
破れ，各綀胞は正常化して行く傾向を示し始め，12時間 後には略正常に近い像を示すが，空胞は未だ残つてい る.24时間後にもF型で正常に近いが空胞が未だ残つ ている.48時間後も少し空胞があり，線維牙緗胞が少 し現われて来ているが，未な゙完全な正常像ではない． 3 日〜 1 週間で正学像に復する(装U1).

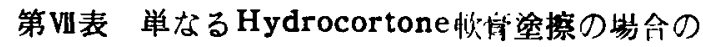
二十日鼠の皮下結合樴線組系の\%

\begin{tabular}{|c|c|c|c|c|c|c|}
\hline & \begin{tabular}{|l} 
線維 \\
細胞 \\
\end{tabular} & 線組球 & 組維 & 単核 & 白血脙 & 線和采型 \\
\hline 正 常 & 71.34 & 11.75 & $\mid 13.12$ & 1.23 & 2.56 & $\mathrm{~F}$ \\
\hline 1 時間後 & 71.04 & 11.64 & 13.62 & 1.56 & 2.14 & $\mathbf{F}$ \\
\hline 3 時間後 & 69.67 & 11.93 & 13.64 & 1.75 & 2.01 & F \\
\hline 8 時間後 & 70.75 & 12.11 & 12.36 & 1.23 & 3.55 & F \\
\hline 24時間後 & 71.06 & 11.53 & 13.58 & 2.01 . & $1.88^{i}$ & $\mathrm{~F}$ \\
\hline 3 日 後 & 72.01 & 11.55 & 13.36 & 1.63, & 1.45 & F \\
\hline 1 週間後 & 71.44 & 11.77 & 13.21 & 1.32 & 2.26 & $F$ \\
\hline
\end{tabular}

2) Haematoxlin-Éosin 重染色標本所兄

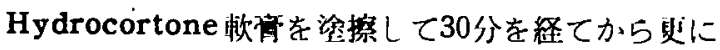
1 時間後では充血と浮腫が僅かに認められたのみてあ る. 3 時間後には变化を認めないがてつ後も特微つあ る变化を認めない。

3) 小括

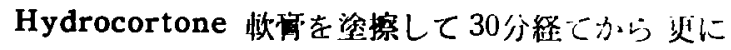

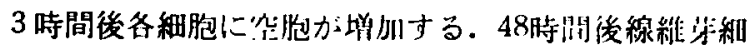

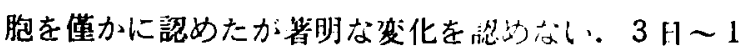

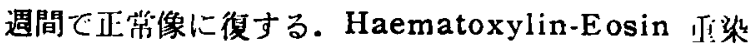
巴標本では一層兄るべき変化がない。

\section{第4章考按と総括}

Finalgon 軟亩はリウマチ性矤患やスホーーツ外做等

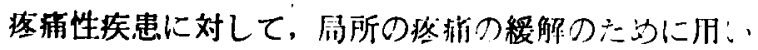
られて居り,作用機転については2㮔粸の各ヶ们洞機序 を異にする有妇主成分があつて, 则ち $\beta$-butoxyethyl ester of nicotinic acid は毛科血管の主律种経老粦

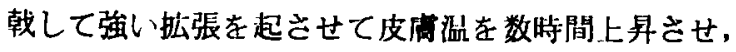
Nonylic acid vanillylamide は主に皮膚の感絖神 経終末に作用し，二次的に毛紐血管の払張を起させる とAchinger(1952)1'は云つている.Plötze (1952)7 によれば両有効成分によつて相案奻果を現わすと云 い, Jung (1952) 多) は単なる相乗作用でなく促つて 繰返して用いても作用は失われないと云い，Hensel, Brück and Seraphin(1954)の゙にれば, Finalgon 軟使用により局所の血流星は初めの5 倍に上年し20 分で最高になり，2 時間後もなお上年していると云う.
私の人に於ける臨床研究では，皮成滥の上年と，局 所の炎症および疼痡の䌅解等の点について検討して他

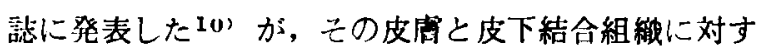
る影蠁を検討した。

比校に用いた芥子泥署法の作用は揮発性䒚子油に依 るものである. 芥子泥毾法やその他の種々の方法で。 皮下結合䄉線組采が賦活される事力閔教授や同教授門 下によつて報告されているいか11》。

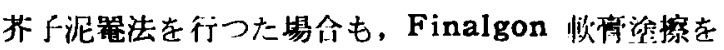
行つた場合も，操作を終つてから4時間月頃を極期と

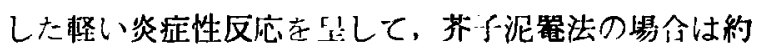
1 週問で,Finalgon 忺埥の場今は数日で略↔正常に 懦つている。線組系も 4 時間日頃に最も賦活された状 態にあり，同様に数日から 1 週間で正常に㷌つている

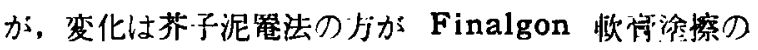
場命よりも強く, 正常化も少し遅いようである。

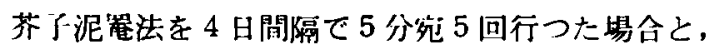
Finalgon 軟意を30分纺 4 日間隔て 5 回行つた場合と を比较して見ると，何れの場命も5回目の操作直前の

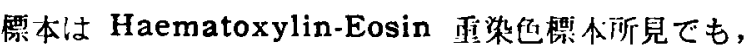

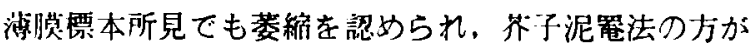
Finalgon 㳄幅の場令よりも强く，5回月の操作後は

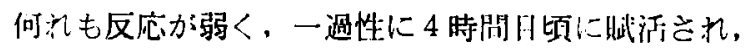

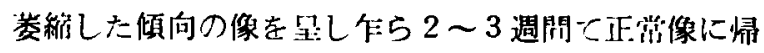

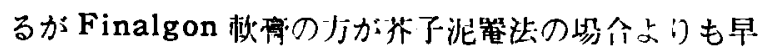
‘正常像に㷌るようてああ。

芥子泥は発生する揮発性芥子泪の強さが必ずしも一

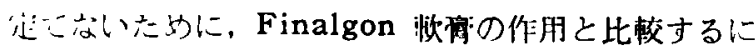

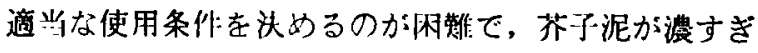
る事や，薄才ぎる小，罨法の跡に㹢皮を結儿坛り，膿 疮を形成したりする事があつたが，私は使朋条件をを定 力，使用後に芥子泥をよく拭い去る事によつて，こ犷 等の悼を克服する事が代来た。

以上の結果より文苚及び皮下結合織に刘する直接の

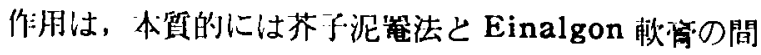
に差異を認められなかつた串になる。僧し芥了泥囎法

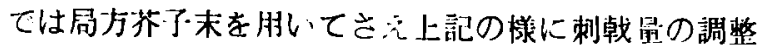

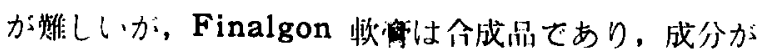
一定して居り，使用量の調邻が容易であるつテ棺に期

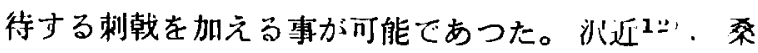

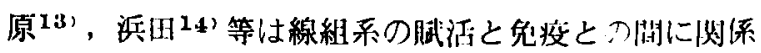
を見出したと云つており，人野口等は形留緗胞が抗 体産生系の主たるものであると見なしている．Final-

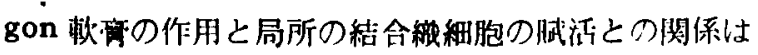

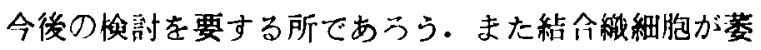


繀して賦活されにくくなると云う事と, Finolgon 軹 高の局所の総合的作用との関連は臨㕅䒠歌も含めて慎 重に検討する事が必要であうう。

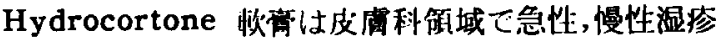
其の他に使用されてよい結果を得られている.また

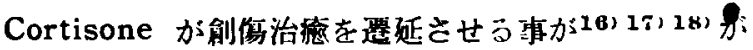
報告さ扎て居り，平井101も办 Hydrocortisone, Predonisolone の全身投与によつて，肉芽形成が著 明に抑制ジるのを認心亡。

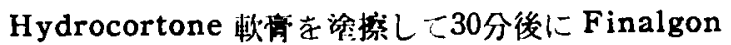

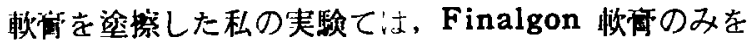
染徖した場合よりも皮应およじ皮下結合織細胞の反応 は弱く Haematoxylin-Eosin 重染色標本こは 4 時間後に軽い充血と軽度〜等度の浮腫を真皮層に 認めたに過きす，皮下線組系も僅かに倵活されたに過 ぎなかつた，此の事より Hydrocortone 顿詴か：Fin・ algon 軟等の刺戟作用を抑制したのではないかと考污 られる.Jung ${ }^{8}$ は Finalgon 軟育の充血作用と，皮 凮に対する直接の作用とを分けて考えているが，此の

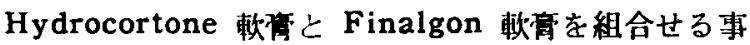
により，Finalgon 軟商の血流星增加の作用と皮卜結 合織賦活作用とを分離ざる事が可能であるかも知れ ないか，更に検討を要する問通であうう。

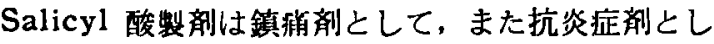
て使用㤩れ，平井1日は少最の全身投与ては強い抗炎

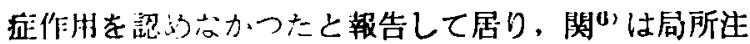

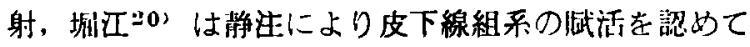
(る. Calenick \& Bentner'1), Cavenberge2ม) は，アスピリンは解熱镇痛效果と问時に間脳一下垂体

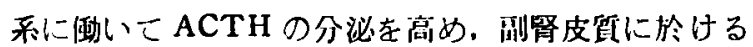
Hydrocortisone の産出を促すとしている. 山崎等 2:3 は Salicyl 酸製用はHistamin 避雄を抑倐する と考沉ている。

私の $5 \%$ Salicyl 酸 Natrium 祝水性:Vaselin 枚
韦24”を塗擦した実験では皮庥の充血，浮腫，表皮角 賀層の㔀離老埾度に認めるにすぎす，線組系の䟼活も 柽度であつた。

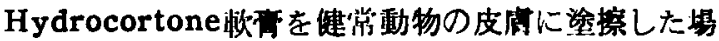
合も剌戟作用は見るぺき程でなかた。

\section{第5章 結䃞}

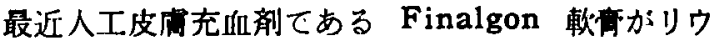
マチ性疾腎やスポーツ障害に用いられているが、私は その作用機転の追求として，皮成およひ皮下結合紻線 組系に及ぼす作用を茶子泥その他のものを対照として 檢討して次の結果を得た。

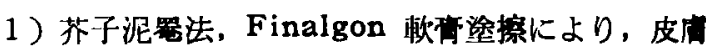
は刺戟されて軽い炎症性反応を示し，皮下結合織線組 系は赋活される。乙の变化は芥子の方が強い。

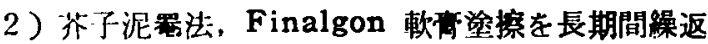

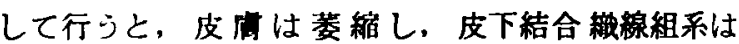

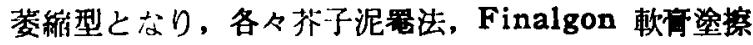

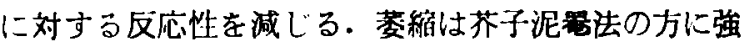
い.

3）芥子泥署法は刺戟冒の調節が難しく,Finalgon 顿掊は調節が容易である。

4) Hydrocortone 㳄常と Finalgon 軟等とを組 合せて用いると，前者が後者の刺戟作用を抑制し，皮 虚の反応も，皮下結合織線組系の倵活も軽くなる。

5) $5 \%$ Salicyl 酸 Natrium 視水性 Vaselin

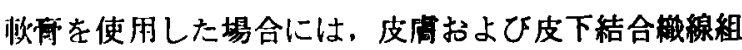
系の反纫は軽度てあり，Hydrocortone 板重使用の場 合には更に柽廝の反応しか示さない。

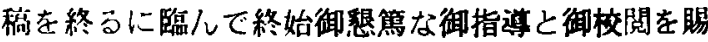
つた恩们沉玉教授に対し深苫の謝意を表すると北に， 種々御援妙在頂いた本学解缡学教室関教援、病理学教 室粟井笸们に心から㴬意を表します。

\section{主要参考文献}

1) Achinger, F.: Arzneim.-Forsch., 2, 3611952.

2 ) 奥田三友 : 解剖誌, 22, 348, 昭19.

3) Möllendorff, W. u. M. V. : Z. Zellforsch., 3, 1926.

4) 関正次 : 病理䛸， 1，584, 昭 17 .

5 ) 関正次 : レフラ, 25, 60, 昭31.

6 ) 成正次:日租碌，1，131, 昭25.

7 ) Plötze, B. : Arzneim.-Forsch., 1. 305, 1951.

8 ) Jung, K.-H. : Inaugural-Disseration, Marb. urg, 1952.

9) Hensel, H. etal : Zschr. Rheumaforsch., 13, 1,1954 .

10）名越呚：リウマチ，1，(投稿中）

11）大源秀城：日組録，1，27, 昭25.

12）沢近芸：日組録，1，486, 昭25.

13）桑原四郎：日組镍，5，223，昭28.

14)浜田幸子：日組錔，6，453，炤29。

15 ) 天野重安：最新医学，13，815, 炤33. 
16) Spain, D. M., Molomut, N., Haber, A., Am. J. Path., 26, 716, 1950.

17）策谷茂夫：神医紀要，9，15，昭32.

18) Plotz, C. M., Howes, E. L. et al, Am. J. Path., 26, 709, 1950.

19）平井俊作：岡山医誌，71，895，1959.

20）垭江正美：日組録 $3,215,1952$.
21) Calenick \& Bentner: c. f. Cochran, Brit. Med. J., 164, 727, 1951.

22) Cavenberge, H. V. : Lancet, 2, 374, 1952.

23）山崎英正他：䑁碟医学最近の進步， 2 等，253, 昭31.

24）小堀辰治：皮情性病科雑誌，62，21，昭27.

\title{
Experimental Studies on the Changes of Skin and Subcutaneous Connective Tissue in Application of Rubefacients
}

\author{
By \\ Tsutomu Nagoshi \\ From the Department of Orthopaedic Surgery, \\ Okayama University Medical School \\ (Director : Prof. Dr. Toshio Kodama)
}

The effect of Finalgon ointment, mustard plaster and other medicines on the skin and fibro-histiocytic system of subcutaneous connective tissue were investigated.

1) By application of mustard plaster and of Finalgon ointment, the skin was stimulated and showed slight inflammatory reactions, and fibro-histiocytic system of the subcutaneous connective tissue was activated, being much intensive in mustard plaster.

2) The responsiveness of the skin and fibro-histiocytic system of the subcutaneous connective tissue to mustard plster and Finalgon ointment was weakened by the repeated application in a long period of time.

The skin and fibro-histiocytic system of the subcutaneous connective tissue became atrophic, and intensity of the atrophy was severer on the mustard plaster.

3) On the mustard plaster application, adjustment of stimulation dosis was difficult, but easy on the Finalgon ointment.

4) On the combinated application of Hydrocortone ointment and Finalgon ointment, the action of the latter was restrained by the former.

5 ) On the application of $5 \%$ hydrophilic petrolatum, the reactions of the skin and of fibro-histicytic system of the subcutaneous connective tissue was weak, being less on the application of Hydrocortone ointment. 


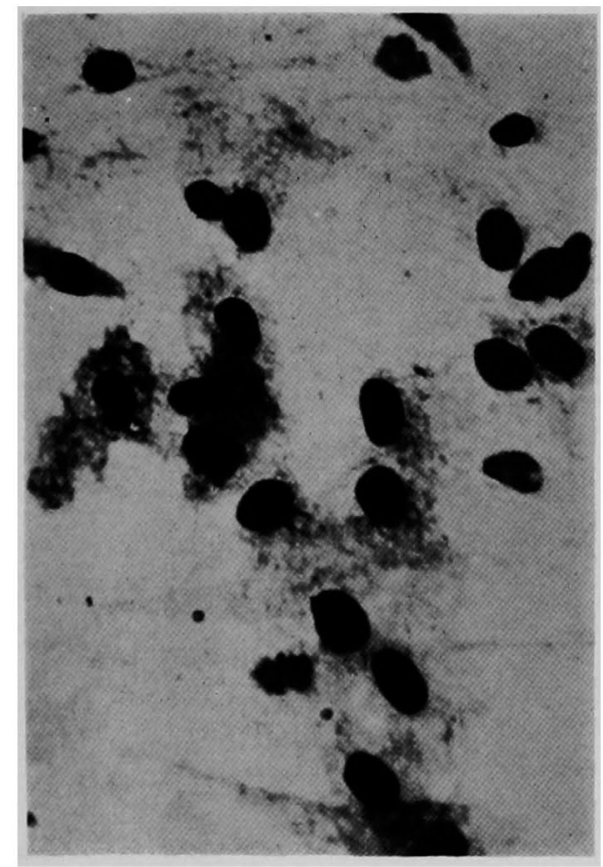

写真 No.1 二十日鼠皮下粗柱結合組織正常像，

各租胞は安定している

鉄へマチンラツク染色 $400 \times$

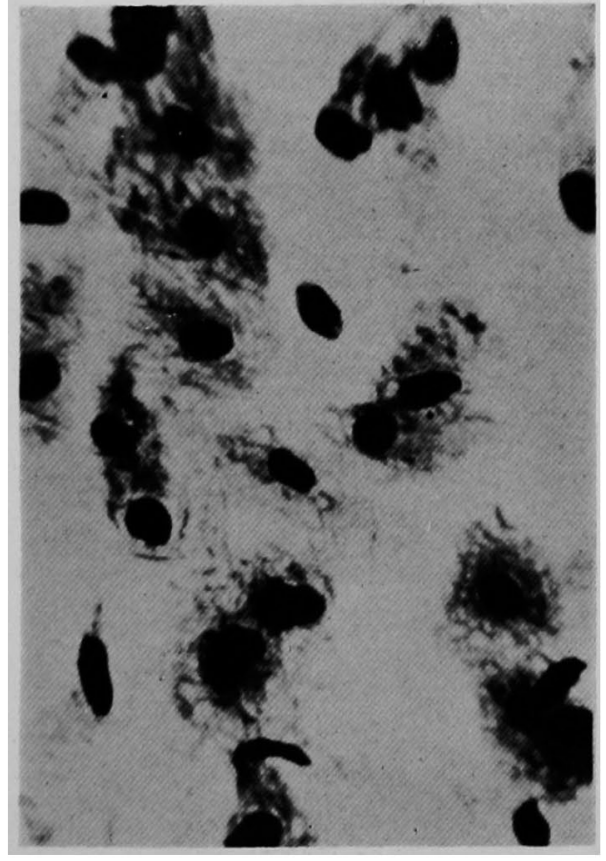

写真 No. 2 二十日鼠皮下粗性結合組, 芥子崖法 10分問の後 4 時間月 組織球, 線組球 が多数現れ珷活されて空胞に䔰む 鉄ヘマチンラツク染出 $4.00 \times$

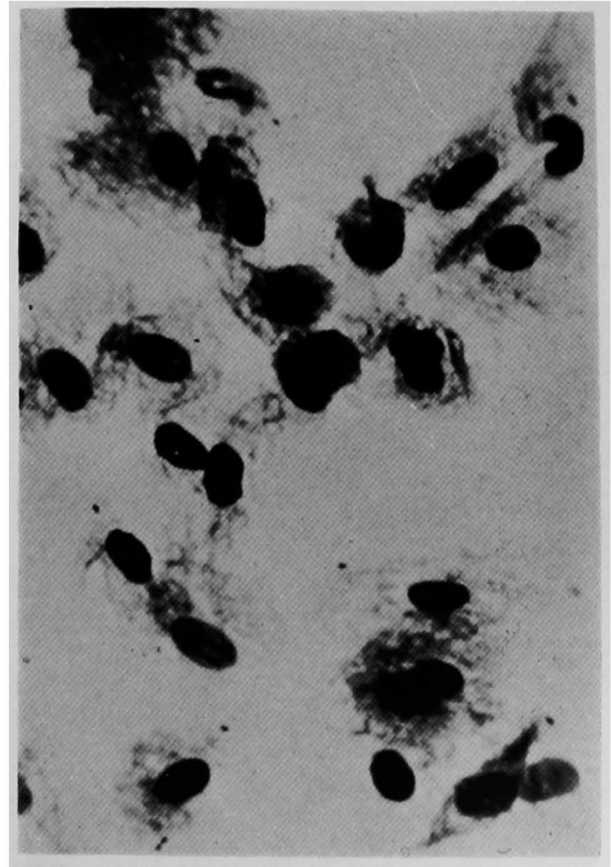

写真 No.3 二十日鼠皮下粗性結合組紋, Finalgon

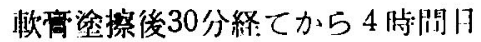
組織球，線組球が多数现れ倵活至れて 空胞に富む 鉄へマチンラツフ染出 $400 x$ 


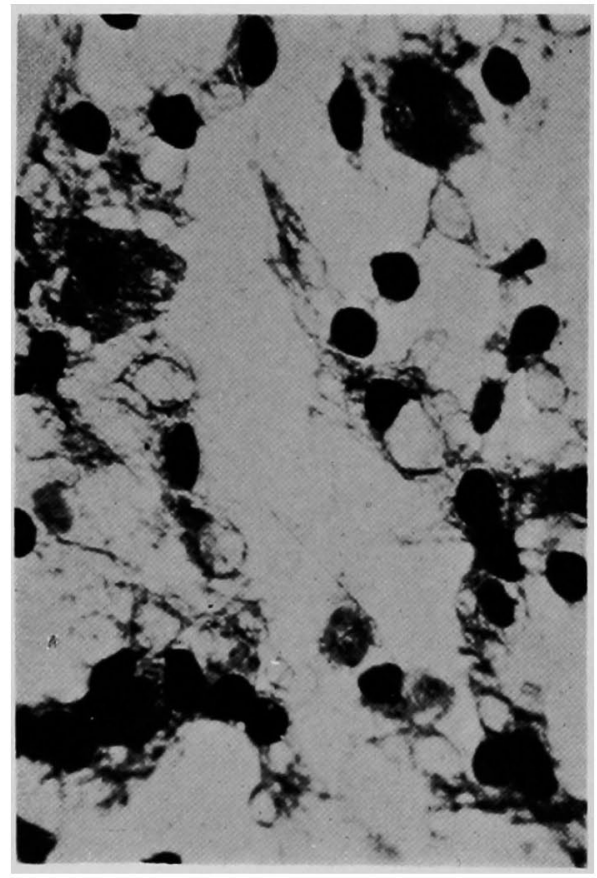

写真 No.4 二十日鼠の皮下粗性結合組織, 芥子 炭法を5分㱜 4 日間滆で行い5 回目 崔法の挋前, 稩胞は萎縮し胞体が少 忘し。鉄へラチンラツク染色 $400 x$

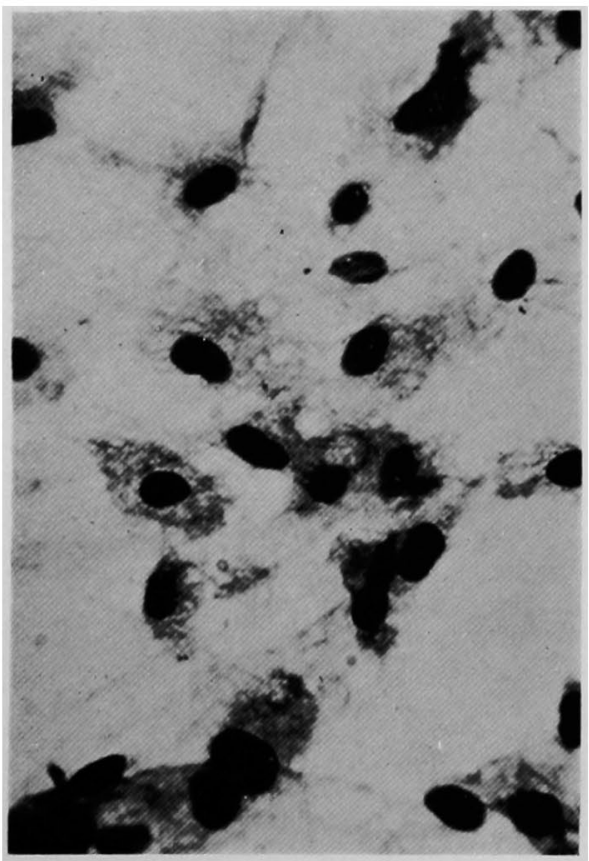

写真 No.6 二十日鼠の皮下粗性結介組織, 芥子嬵 法老 5 分宛 4 日隔で行い 5 回目の緟法 を行つた後 4 恃問百，組胞は胞体を增 し丸みを滥して来ているが埾度であ る。 $400 x$

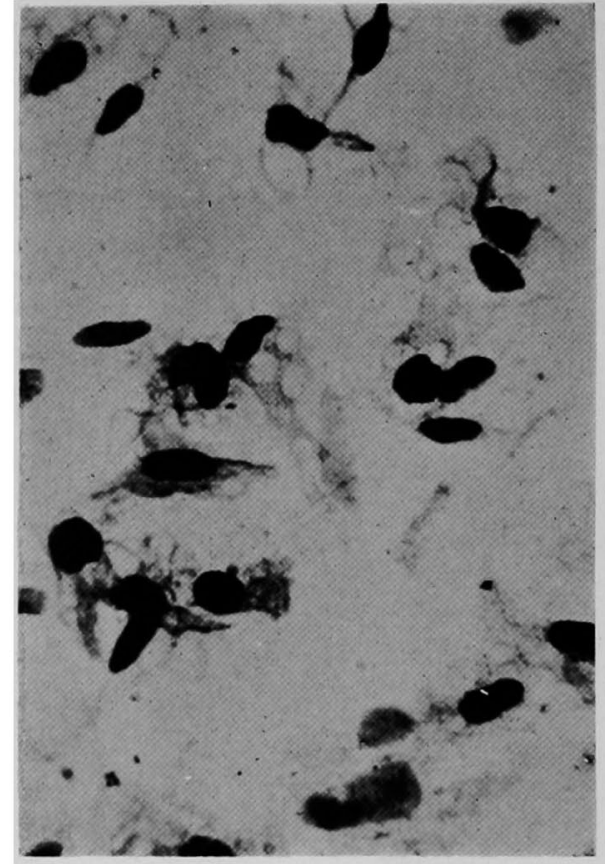

写-真 No. 5 二十日鼠皮下粗性結合組織

Finalgon樕高を 30 分宛 4 日間隔で使用し 5 回目叙擦の直削，細胞は萎縮し胞体が 少ない。鉄へマチンラツク染色 $400 \times$

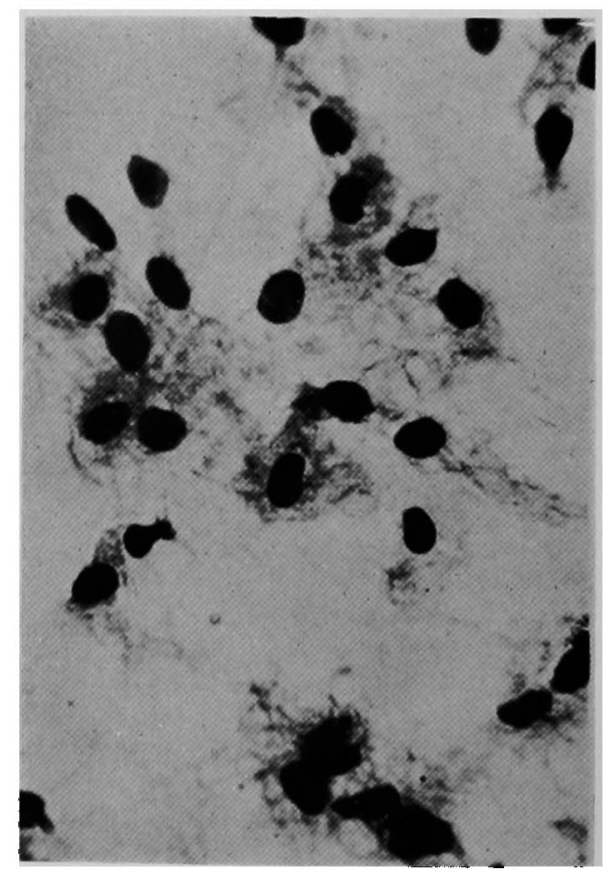

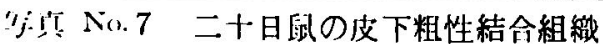

Finalgon 忺高を30分宛 4 日間隔で使 用し 5 回日の答擦後 4 特間日, 細胞は 胞体を斻しぬみを沙して来ているが軽 度である。空胞も增している。 $400 \times$ 